Основой формирования отношений обучающихся и учителя являются следующие выбранные виды и формы деятельности: лекция, практикум по решению задач, индивидуализированная самостоятельная работа по уровням, индивидуальные консультации, зачетные работы по уровням. Как видно из предложенной модели, в процессе обучения отдается предпочтение увеличению доли самостоятельной работы обучающихся. Этого можно добиться за счет обеспечения обучающихся необходимым учебно-методическим обеспечением в электронном и бумажном вариантах. Педагог выступает в роли консультанта, источника дозированной помощи, контролера и корректора результатов обучения. Обучающийся принимает роль активного участника - субъекта образовательного процесса. Используемая рейтинговая система контроля знаний дает возможность прослеживания результатов обучения системно, на протяжении всего процесса обучения, открытость предъявляемых требований к уровням усвоения обуславливает возможность самоконтроля и своевременной самокоррекции знаний. Обучающийся сам ответственен за выбранную индивидуальную траекторию обучения, за ожидаемые результаты своей учебной деятельности. Таким образом, у обучаемых повышается самосознание, развиваются саморегуляция и объективность самооценки, пробуждаются самоопределение и самоутверждение. Тем самым происходит процесс самообразования личности обучающихся, что есть, осознанное овладение знаниями и как, результат, повышение уровня образованности, в частности, уровня образованности по геометрии.

Обучающийся выполняет самостоятельную индивидуальную работу по выбранному уровню и по окончании изучения темы выполняет промежуточную контрольную работу (это может быть тест или устный зачет) в соответствии с критериями, предъявляемыми по заявленному уровню обучения, в случае не соответствия знаний, он повторяет курс данной темы (данный момент показывают на схеме стрелки при выходе из каждой темы). В конце изучения всего модуля проводится работа по итоговому контролю знаний. Если по результатам данного контроля слушатель показывает знания ниже базового уровня, хотя по одной из изученных тем модуля, то ему рекомендуется коррекция знаний по этой теме и он возвращается к повторению и выполнению заданий этой темы (тема может быть не одна, а несколько).

Главная цель предлагаемой технологии дифференцированного обучения является не только вооружение обучающихся набором, а, самое главное, развитие у обучающихся регулятивных компетенций: самоконтроля, самооценки, навыков самоорганизации, осмысленности обучения, самостоятельной деятельности. Все вышеперечисленные компетенции в дальнейшем будут способствовать не только осознанному самообразованию, верному выбору дальнейшей профессии, но и станут неотъемлемой частью всей последующей жизнедеятельности и профессиональной деятельности.

Таким образом, в данной статье мы постарались раскрыть основные виды деятельности обучающего и педагога при деятельностном подходе к обучению, показали какие методы и средства применяются при реализации технологии дифференцированного обучения, указали необходимое учебнометодическое обеспечение и описали процессуальный аспект технологии.

\section{Литература}

1. Александров А.Д. Основания геометрии. М.: Наука, 1987. -288 с.

2. Индивидуализация и дифференциация обучения в вечерней школе: Пособие для работников веч. (смен.) шк. / Под ред. Г. Д. Глейзера. - М.: Просвещение, 1985. - $143 \mathrm{c}$.

3. Фройденталь Г. Математика как педагогическая задача: Книга для учителя / Под ред. Н.Я. Виленкина. - М.: Просвещение, 1983, стр.40.

\title{
INTERRELATING LEADERSHIP BEHAVIOURS AND ORGANISATIONAL CULTURES
}

\author{
Jakipova Larissa Sakhievna \\ MA, senior teacher, \\ Almaty Technological University \\ Almaty, Kazakhstan \\ Smakova Gulyaim Zhangalievna \\ MA, senior teacher, \\ Almaty Technological University \\ Almaty, Kazakhstan \\ DOI: 10.31618/ESU.2413-9335.2019.5.59.11-13
}

\section{ABSTRACT}

Due to globalization, the conventional hierarchical organizational structures are outdated. This means that new cultures and values are spreading rapidly in the business world. This has led towards the development of variety of organizational cultures and leadership behaviours. Hence, it is extremely important for the modern leadership to mould their behaviours according to corporate culture or vice versa.

The purpose was to find out that is there any correlation between leadership and organizational culture? How do they impact on each other? The research was carried out to determine the position of organizational culture with respect to leadership.

The implementation method used to carry out this study was literature review. Electronic sources, books and articles were used for the fulfillment of aforementioned task. The research is based on a qualitative approach. 
Keywords:Leadership, Organizational culture, Transformational leadership, Charismatic leadership, Transactional leadership, Team leadership

Introduction

Due to globalization, the conventional hierarchical organizational structures are outdated. This means that new cultures and values are spreading rapidly in the business world. Those leadership approaches that were designed for the hierarchical networks cannot be accommodated anymore [1, p.298]. Therefore, there is a growing tension that these traditional leadership styles will not be able to function properly in today's complex business sphere [2, p.13]. All of this has led towards the development of variety of organizational cultures and leadership behaviours.

According to Robbins \& Coulter, Organizational culture is the set of values and beliefs that are possessed by the employees working in an organization. Since, the organizational culture consists of behavioural norms; it has a major effect on staff's attitude and their style of work. Due to this quality, it is extremely important for the management to take into consideration different dimensions of its corporate culture that has an impact on job satisfaction, employee performance and commitment. An organization consists of staff members. Therefore, staff's behaviour will influence the organizational performance. This makes it important to investigate that how does an organizational culture induce a change in the attitude and nature of the management practices. The management often has to adjust its leadership behaviour in order to meet the organizational goals. There are many aspects that can cause a change in the leadership styles. Most of the previous researches emphasized on the instrumental consequences of the leadership. This means that how can leaders vary their styles based on the individual factors such as personal values, personality traits and leadership skills in order to impact positively on the organizational outcome [3, p. 149].

On the other hand, there are a very limited amount of researches that focus on the organizational level-how does the organizational culture impact on the variation of leadership styles. The administrators have to understand that how can they mould their leadership norms according to the corporate culture and vice versa in order to meet the organizational goals. Is there any correlation between these two elements? How do they impact on each other? This research is carried out to determine the position of organizational culture with respect to leadership. There are many dimensions of organizational culture and some of these dimensions are more important than others such as leadership. If any of these dimensions are threatened, it can easily lead towards the destruction of company goals and aims. Employees begin to lose their motivation and job satisfaction that can cause the organization to be ineffective and inefficient. Hence, the researcher has tried to establish a relationship between the leadership aspect and the organizational culture in order to avoid any conflicts between these two elements.

\section{Data Collection}

Data collection was performed in an iterative manner to retrieve articles from Google Scholar and Science Direct. In total, five imperative articles were found. Those articles were related to leadership, organizational culture and organizational performance.
These articles focused on establishing a linkage between leadership styles and organizational culture, however, their approach was different. In order to put further emphasis on the research, articles related to the types of leadership and organizational culture were also explored. To make the articles hunt more effective, a 'bottom up' search strategy was used. The reference lists of each article were reviewed thoroughly for finding out additional researches related to the topic in question.

The total number of articles obtained from the databases was twenty six. All the extracted articles were somehow related to the phenomena of leadership and organizational culture. Thirteen articles were found from Google Scholar, five were fetched from Science Direct. Search terms included "relationship between leadership and organizational culture", "impact of organizational culture on leadership and company's performance", "types of leadership", "types of organizational culture", and "leadership and organizational culture." The reviewers read each article, and evaluated its reliability. All those studies were considered that fulfilled the searched criteria. Some articles met more than one criterion, and some were able to accomplish exactly one. The rest of the researches were excluded after detailed reviewing, since, they failed to provide with conclusive findings that can serve the research question with admissible answers. However, assistance was taken from the omitted studies in the formation of theoretical basis. The total sum of discarded studies was approximately 21 .

\section{Data Analysis}

The research method used to carry out the study was literature review. This research is based on a qualitative approach. The reason for choosing the qualitative approach was that this study is explanatory. The primary purpose of this study was to provide with the opinions, motivations and understanding of the concepts in order to gain an overall picture of the whole scenario. It does not contain any numerical analysis but it forms a hypothesis for future quantitative research. The sources used for the qualitative data consisted of various electronic sources such as articles, journals and books. Theory provided a strong foundation for this study without any interference with the investigation.

As stated earlier, this study falls into the category of qualitative research. The type of research is explanatory, since it is guided by the research questions. The organization of data in this study was done by performing data cleaning and labelling. Labelling was done by structuring the information and familiarizing with it. Secondly, the framework was identified in the beginning of the study. It was clear from the start that this research has an explanatory framework. Since this study was not guided by the data, it could not be categorized as an exploratory research. The identification of the framework supported in structuring, labelling and defining the data.

\section{Theoretical Basis}

Leadership and Performance

The research on leadership phenomenon has been going on for several years, but most of these researches 
isolated leadership from other important factors. Nowadays, research interest has been diverted toward the effects of leadership traits on the organizational performance. Fiedler [4, p.241] had argued that the efficiencies and the capabilities of a leader have a significant effect on the performance of a group, a company, or an entire country. Darcy \& Kleiner [5, p. 12] stated that the only way for an organization to survive against all the pressures that may originate externally and internally is to develop and train effective leaders that can cope with them.

Leadership and Organizational Culture

It is easily noticeable that the organizational performance has a solid connection with culture and leadership aspects of a company. Therefore, it is extremely important to create a harmony between organizational culture and leadership in order to bring about a positive change in the performance of a corporation. If there will exist a dissension between them, it will cause anarchy in the organization's environment.

Bass [6, p. 86] evaluates the linkage between organizational culture and leadership by considering the impact of different leadership styles on the culture. He states that transactional leaders are usually steered by

\begin{tabular}{|l|}
\hline Culture Type \\
\hline Adhocracy \\
\hline Clan \\
\hline Market \\
\hline Hierarchical \\
\hline
\end{tabular}

The results of this study were based on the secondary data. Secondary data was further classified into five recognizable researches. The goal of all the researches was same, yet their findings were distinctive in nature. The Information from theory and the findings of various studies certainly emphasized on establishing a relationship between leadership and organizational culture, however, there was a great deal of variation in their conclusions.

Adhocracy culture should focus on developing transformational leaders, on the other hand, found out that transformational leadership is a misfit with adhocracy values. It is essential to note that the finding is in harmony with the established literature, but result is incompatible with the theoretical foundation. The reason can be an extreme difference in the nature of their subjects. One study focused on the hospitals, and the other one concentrated on the opinions of multi- industry CEOs. Literature stated that market culture mostly focuses on task completion, and transactional leaders are the ones that can achieve this aim in the finest possible manner. In spite of that, the outcome by affirming that innovation is the key to survive in today's fierce market competition, therefore, transformational leadership is the most reasonable style for market culture values. the culture, whereas, transformational leaders have the skills to shape the organizations according to their own vision.

Extensive literature review assisted in identifying four factors of leadership style and organizational culture. Results of this study clearly showed a healthy relationship between leadership and corporate culture. Furthermore, [7, p. 571] carried out interviews with a total of 53 CEOs from diverse range of industries, and related organizational culture values with the personality traits of a leader. According to them, CEO agreeableness and emotional stability is applicable with the clan culture. On the other hand, his emotional stability is negatively related to adhocracy culture. Moreover, leader's openness to experience is negatively related to the adhocracy and hierarchical cultures; however, his agreeableness trait is positively related with the adhocracy cultural values.

Results of this study clearly showed a healthy relationship between leadership and corporate culture. Clan culture is positively related with team leadership. Transactional leadership is tailor-made for market culture, and hierarchical culture is suitable for charismatic leadership style. See table 1

Suitable Leadership Style

\section{Transformational}

Team

Transactional

Charismatic

\section{References}

1. Uhl-Bien, M., Marion, R., \& McKelvey, B. (2007). Complexity leadership theory: Shifting leadership from the industrial age to the knowledge era. The Leadership Quarterly, 18, 298-318.

2. Hazy, J. K., Goldstein, J. A., \& Lichtenstein, B. B. (2007). Complex systems leadership theory: An introduction. In J. K. Hazy, J. A. Goldstein, \& B. B. Lichtenstein (Eds.), Complex systems leadership theory: New perspectives from complexity science on social and organizational effectiveness (pp. 1-13).

3. Harrison M. Trice and Janice M. Beyer (1991),"Cultural leadership in organizations," Organization Science, 2(2), pp.149-169.

4. Fiedler, F.E. (1996) 'Research on Leadership Selection and Training: One View of the Future', Administrative Science Quarterly, 41: 241-50.

5. Darcy, T. and Kleiner, B.H. (1991) 'Leadership for Change in a Turbulent Environment', Leadership and Organization Development Journal, 12(5): $12-16$.

6. Bass, B.M. (1985) Leadership and Performance Beyond Expectation. New York: The Free Press.

7. Egri, Carolyn P., Susan Herman (2000)," Leadership in the North American environmental sector: Values, leadership styles, and contexts of environmental leaders and their organizations", Academy of Management Journal, 43(4),pp. 571-604. 